All of this, morcover, will be taking place within the context of a thoroughly reorganised nuclear industry. Plans for conventional plant will continue to focus on the pressurised water reactors. Looking ahead, France expects that the new generation of fast breeders will be needed in the 1980s. That is why Superphénix received the go-ahead earlier this year. And the fact that France has secured the cooperation on the project of both Italy and Germany while retaining a $51 \%$ interest for EDF is of perhaps greater consequence to many of those awaiting a British decision on the fast breeder than the debate on its implications which is now growing in all the industrial countries.

- The final contract for the controversial Franco-South African deal involving the sale by a French consortium of two nuclear power plants to the South African Electricity Supply Commission (Escom) were not signed by the deadline of July 31 last week following the development of a complication, apparently over safeguards attaching to the deal. A South African delegation left Paris after 24 hours of talks without having signed anything, and although French spokesmen sounded confident this raised doubts about whether the deal would go through. It now appears that an agreement concerning safeguards was later initialled in Paris and will be submitted to the International Atomic Energy Agency and Euratom. It is thought that once this is accepted, it will pave the way for the signing of the main contracts.

\title{
WEST GERMANY
}

\section{Exporting for survival}

West Germany's nuclear industry is not becoming any less involved in the politically sensitive area of exports. $A$ Correspondent reports.

FurTher developments in the field of nuclear exports have come with news of additional moves from West Germany exploiting this increasingly lucrative market. Reports quoting West German Economics Ministry officials and spokesmen for the country's leading power station constructor, Kraftwerk Union, indicate that West Germany has been clearing the way with Nigeria for negotiations to begin on the first sale of a 500-600 MW German nuclear plant to a black African country.

The news coincides with the visit to West Germany of the Nigerian Prime Minister, General Yardua. It also comes just a week after Brazil had signed delivery contracts with Kraftwerk Union for the construction of two nuclear reactors as part of last year's government-to-government agreement, and less than a month after the signing in Tehran of the contract between Kraftwerk Union and the Atomic Energy Authority of Iran for the turnkey supply of two $1,200 \mathrm{MW}$ pressurised water reactors.

With the signing of the latter contract, West Germany has become the first western enterprise actually to conclude a nuclear contract with Iran. The reactors, which are to be built near the city of Bushehr on the shore of the Persian Gulf, were begun this time last year after a letter of intent was issued to Kraftwerk Union in November 1974. Of the 3,800 employees presently on site, about 600 are German expatriates.

Kraftwerk Union describes the plants it exports as the most reliable reactor systems, and generally cites the Biblis plant in Germany in support. In fact, as Rheinisch-Westfaelische Elektrizitaeswerk (RWE) confirmed last week, that station has now revealed technical problems in the course of a planned shutdown, and the length of the closure is now likely to be doubled to four months.

What this means in terms of costs for Kraftwerk Union is uncertain, but it does not expect to operate at breakeven point until the 1980 s anyway. The star of Germany's nuclear industry, the company is crucially dependent on exports to supplement the home market and so render possible the economies of scale necessary to compete favourably with the USA. But some overseas contracts were lost in the first half of 1975. These included the plan for a nuclear power station at Kaliningrad on the Soviet-Polish border, which fell through because of East German objections concerning the supply of electricity, and deals with South Africa, Sweden and Switzerland.

The company also appears to be finding that permits are now taking much longer to obtain, and greater safety measures, among other things, are extending the construction time for the average plant. Germany has its own protectors of the environment too, keen to prevent (or at least delay) construction of plants beyond the ten or so already in operation.

\section{SWEDEN \\ Suffering without support}

Wendy Barnaby reports from Stockholm on the state of basic technical research in Sweden

To live in Sweden is to be impressed by the sophistication of the country's technology: a level of accomplishment which thrives on extensive research and development. There is, however, one part of this body of excellence which is ailing. Basic technical research is, in fact, close to death.

Nobody seems to know exactly what basic technical research is, but everyonc agrees that it is conducted for the extension of knowledge, without any specific application in view-although it may of course be used if the necessary techniques are developed. It is also differentiated from pure fundamental research, which has no possible or likely practical application and which is supported in Sweden by the Natural Science Research Council. Opinion is unanimous, too, on the extent to which basic technical research is presently being supported. In the words of a spokesman at the Academy of Engineering Sciences, it is being given "no money at all".

This is hardly an exaggeration. Its needs used to be met by the State Technical Research Council. This body was disbanded in 1968 and replaced by the Swedish Board for Technical Development (STU) whose emphasis has been on supporting applied research, specifically of the sort that will further innovation and technical expertise in Swedish industry. Including governmental and industrial outlays, Sweden spends about Sk4,000 million (about $\$ 900$ million) annually on research and development. For the 1975-76 financial year, STU's budget amounted to about \$56 million, of which-according to a spokesman there-about $\$ 10$ million was devoted to basic technical research.

Or, rather, to some types of that research. For there has been a reorientation of grant-giving to favour certain areas of "big" science-space and elementary particle research, for example. This has resulted in fewer numbers of bigger grants being given in these areas, rather than a multitude of smaller grants covering a broader 